\title{
Bird flu: crossing borders
}

\section{Despite recent reports from governments that bird flu is under control, it continues to spread through Asia's poultry and claim lives - there are even signs of human- to-human transmission. Declan Butler tracks the disease's inexorable spread.}

\section{VIETNAM}

On 14 July the official Vietnam news agency reported no new human cases of avian flu since 4 June, and said that the government felt infection had been "well-contained". But the same day the Tien Phong newspaper reported a further human death, as well as three known and a dozen suspect cases. If confirmed, the death would bring the country's total to 40 , with 20 fatalities since the start of the year.

(r)
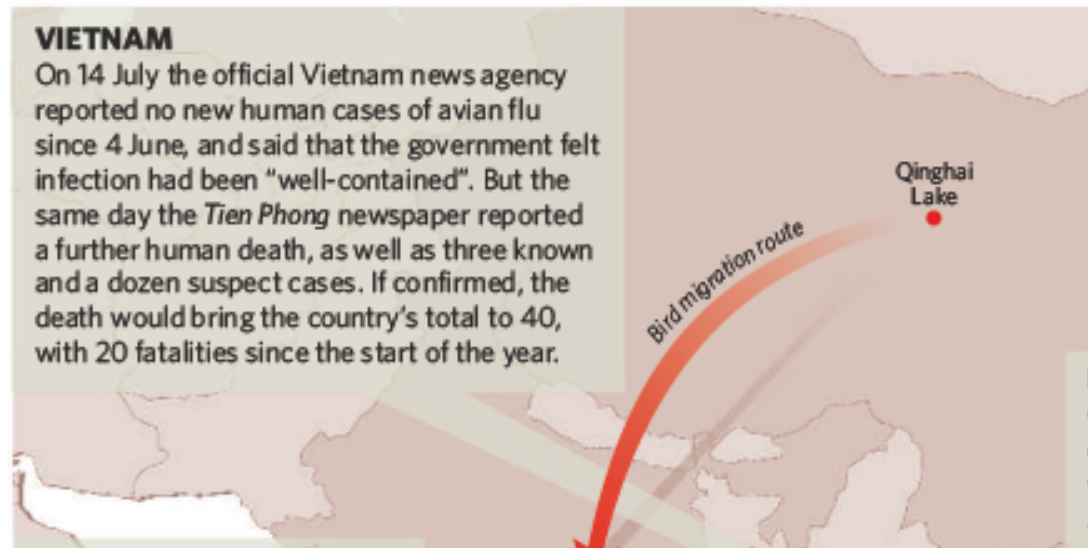

\section{INDIA}

In response to the outbreak of H5N1 among migratory birds in China, India announced last week that it will monitor 50 of their arrival points. Bar-headed geese in particular will migrate across the Himalayas in coming months. Blood samples will be taken from birds and tested in a highsecurity laboratory in Bhopal.

\section{INDONESIA}

The president of Indonesia, Susilo Bambang Yudhoyono, asked his government on 17 July to be open about the suspected deaths from avian flu of three members of the same family. "The cause of their deaths must be made clear," he said. "It should not be covered up."

A one-year-old girl died on 9 July. Her father, a civil servant, died on 12 July and her nine-year-old sister two days later. If the initial diagnosis of avian flu is confirmed, this family cluster would strongly suggest human-to-human transmission. That would be a reason to raise the pandemic alert level from the current 3 to level 4 - the top level (6) corresponds to a global pandemic.

The deaths occurred in Tangerang in Banten province, where in May the highly pathogenic $\mathrm{H} 5 \mathrm{~N} 1$ strain of avian flu was found to be present in almost half the local pigs (see Nature 435, 390-391; 2005). The victims, who lived in a well-off suburb, are not thought to have come into contact with poultry. They would be Indonesia's first

\section{JAPAN}

On 11 July, Japan announced the seventh outbreak of H5N2 bird-flu virus in lbaraki since late June. The H5N2 strain is not yet known to cause illness in humans.

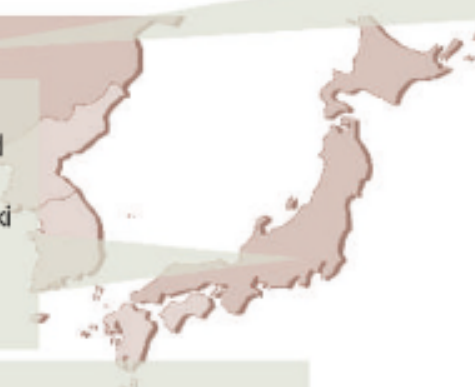

PHILIPPINES

On 8 July, the government announced its first outbreak of avian flu, in ducks living in Bulacan province. Officials were quick to downplay it - agricultural secretary Arthur Yap tucked into chicken at a press conference. On 15 July, the OIE said that tests suggest the virus is an $\mathrm{H} 5$ strain that isn't known to cause serious disease. Samples have been sent to Australia for confirmation. 


\section{CHINA}

Recent headlines from Xinhuanet, China's semi-official news agency, include "Bird flu outbreak in Qinghai 'under control"' and "International organizations 'impressed' by China's commitment in fighting bird flu". They give the impression that China is well in control of the $\mathrm{H} 5 \mathrm{~N} 1$ outbreaks among thousands of migratory birds at Qinghai Lake in western China, and in Xinjiang province near the border with Kazakhstan (see Nature 435, 542-543; 2005).

But this is difficult to verify because China does not allow free movement of international experts or journalists to the outbreak zones. China's grip on information now looks set to be tightened further through new rules that require all research on avian flu to be vetted by its agriculture ministry.

Concerns came to a head on 8 July, when Xinhuanet quoted Jia Youling, director-general of the agriculture ministry's veterinary bureau, as asserting that a paper on the Qinghai outbreak published online by Nature on 6 July "made the wrong conclusion". Jia also accused the authors of never having visited Qinghai, and of carrying out their research illegally because their labs did not meet safety standards and they did not have government approval for the work.

The article's authors included Guan Yi from the Joint Influenza Research Center, run by Shantou University in mainland China and the University of Hong Kong, and Robert Webster, a flu expert at St Jude Children's Research Hospital in Memphis, Tennessee. It concluded that the Qinghai virus is a new, highly virulent form of $\mathrm{H} 5 \mathrm{NI}$, and that the birds risk spreading the virus across Asia as they migrate over the coming months $(\mathrm{H}$. Chen et al. Nature 436, 191; 2005). A paper published simultaneously in Science reached similar conclusions ( $J$. Liu et al Science doi:10.1126/science.1115273; 2005).

Jia objected in particular to an additional conclusion in the Nature paper that the isolates were similar to ones "isolated from poultry markets in Fujian, Guangdong, Hunan and Yunnan provinces during $2005^{\prime \prime}$. China has not declared any avian flu outbreaks in poultry to international authorities this year. "The article's conclusion lacks credibility," Jia is reported as saying. "No bird flu has broken out in southern China since the beginning of this year."

Guan refutes Jia's allegations, saying that his lab meets the World Health Organization's standards for biosafety and collaborates with flu experts around the world. He reiterates that his team found $\mathrm{H} 5 \mathrm{~N} 1$ in samples taken from poultry in the region this year.

Guan interprets Jia's stance as one more example of government 'pressure' on scientists trying to investigate the country's flu outbreaks. On 16 June, the Chinese agriculture ministry warned that it would "regulate and investigate research and testing without permission, to stop unauthorized work". This warning follows a series of rules it published on 31 May, requiring scientists to apply for permission to collect and study $\mathrm{H} 5 \mathrm{NI}$ samples, and to have their results double-checked by the ministry. 